\title{
INFLUENCE OF STAINLESS-STEEL WIRE MESH ON THE MECHANICAL BEHAVIOUR IN A GLASS-FIBRE-REINFORCED EPOXY COMPOSITE
}

\author{
VPLIV ŽIČNE MREŽE IZ NERJAVNEGA JEKLA NA OBNAŠANJE \\ EPOKSI KOMPOZITA, OJAČANEGA S STEKLENIMI VLAKNI
}

\author{
Munisamy Sakthivel $^{1}$, Subramani Vijayakumar ${ }^{2}$ \\ ${ }^{1}$ Adhiyamaan College of Engineering, Department of Mechanical Engineering, Hosur, 635109 Tamilnadu, India \\ ${ }^{2}$ University College of Engineering, Department of Mechanical Engineering, Kanchipuram, 631552 Tamilnadu, India \\ metalsakthi@gmail.com
}

Prejem rokopisa - received: 2016-04-16; sprejem za objavo - accepted for publication: 2016-05-18

doi:10.17222/mit.2016.063

\begin{abstract}
This work covers the fabrication and investigation of the mechanical behaviour of a glass-fibre-reinforced polymer (GFRP) composite embedded with a stainless-steel wire mesh (SSWM) layer. This work takes the hybridising approach in improving the mechanical properties of GFRP through the incorporation of SSWM into the laminates. The structure of the composite is such that the SSWM was placed in the top, middle and bottom of the GFRP. The laminates are fabricated using the hand-layup method with a $40 \%$ weight fractions of epoxy resin, $50 \%$ weight fractions of woven glass fibre and the remainder being SSWM. The mechanical characteristics of the composites are obtained using tensile, flexural, inter delamination and drop weight impact tests. In addition to that, a morphological investigation is made utilizing a scanning electron microscope (SEM). The test outcome demonstrates that the introduction of SSWM leads to far better mechanical properties than GFRP and SSWM in the middle layer has a superior strength compared to other laminates.

Keywords: glass fibre reinforced polymer, stainless-steel wire mesh, mechanical tests, ultimate strength, SEM
\end{abstract}

Delo obravnava izdelavo in preiskavo mehanskih lastnosti polimera, ojačanega s steklenimi vlakni (angl. GFRP) v katerem je vgrajena ploskovna žična mreža iz nerjavnega jekla (angl. SSWM). To delo predstavlja hibridiziran približek za izboljšanje mehanskih lastnosti GFRP z vgraditvijo SSWM v laminate. Kompozit je sestavljen tako, da je bila SSWM nameščena zgoraj, v sredini in spodaj. Laminati so izdelani z ročnim polaganjem 40 masnimi \% epoksi smole, 50 masnimi \% tkanine iz steklenih vlaken, ostalo pa je SSWM. Mehanske lastnosti kompozitov so določene $\mathrm{z}$ nateznim in $\mathrm{z}$ upogibnim preizkusom, $\mathrm{z}$ razslojevanjem in $\mathrm{z}$ udarno žilavostjo. Dodatno $\mathrm{k}$ temu je izvedena tudi morfološka preiskava $\mathrm{s}$ pomočjo vrstičnega elektronskega mikroskopa (SEM). Rezultati preizkusov kažejo, da vstavitev SSWM bolj izboljša mehanske lastnosti kot GFRP, SSWM v sredini pa izboljša trdnost v primerjavi z ostalimi laminati.

Ključne besede: steklena vlakna, jeklo ojačano s polimeri, ploskovna žična mreža iz nerjavnega jekla, mehanski preizkusi, natezna trdnost, SEM

\section{INTRODUCTION}

A composite material is a heterogeneous material that is formed by the combination of two or more materials in order to obtain the favourable characteristics of each. Polymer matrix composite materials are made of fibres embedded in a polymer matrix, also known as fibrereinforced polymers (FRPs). ${ }^{1}$ The fibre is usually made of carbon, glass, aramid and graphite. ${ }^{2}$ The polymer is mostly made of polyester, epoxy, vinyl ester and phenol formaldehyde resins. However, the most commonly used fibre is woven glass fibre that was initially developed for strand off insulator for electrical wiring fibre forming capabilities and is now used almost exclusively as the reinforcing phase in the matrix. Woven roving is available in a variety of weaves, width, weights and finishes to suit a broad range of applications. ${ }^{3,4}$

Composites made with woven glass fibre are finding application in a variety of engineering fields due to their low cost, low weight, high stiffness and corrosion resistance. Fibre-reinforced polymers (FRPs) are utilized to fortify the auxiliary individuals, even after they have been seriously damaged. Woven glass fibre improves the impact resistance, toughness and energy absorption for the composite. The vicinity of woven glass fibre tends to expand the disintegration wear rate of the composite. The Young's modulus can be enhanced by increasing the volume of fibre in the composite. ${ }^{5,6}$

Though the glass fibre has vital mechanical properties but still the other fibres such as carbon fibre, aramid fibre, ceramic fibre, provide better mechanical properties compared to the glass fibre. The major drawback of these fibres is high cost and less abundance. In day-to-day life, the trend is to obtain the high strength material at low cost. So some modification must be made to improve the mechanical properties of glass-fibre-reinforced polymer (GFRP). Numerous methods have been employed such as matrix toughening, fibre hybridising and many more. $^{7-9}$ The major drawback of hybrid FRPs strengthening is the high cost of the different FRPs materials. The FRPs have some drawbacks such as while fitting as 
well as joining applications in the fibrous environment it will not withstand total failure load. This leads to delamination and fibre damage. ${ }^{10}$ Minimising the uses of metallic inserts in the fibrous environment can increase the entire failure loads, which prevent continuous fibre cut off. ${ }^{11,12}$ To stabilise the fibre structure, drilling a hole before riveting the wire mesh is used as reinforcement material to minimise the wear of fibre in polymer matrix. Between two FRP layers amid the shaping operation, the open metallic structure is infiltrated by the polymers, and hence, the metallic structure is completely embedded in the polymer matrix..$^{13,14}$

The GFRP laminate composites are layered materials based on a stacked arrangement of SSWM and fibrereinforced epoxy resin. The SSWM is introduced at the top, middle and bottom of the laminate. The main objective of this work is to investigate the effects of the SSWM layer in the glass-fibre-reinforced epoxy composite under mechanical testing such as tensile test, flexural test, inter delamination test and drop weight impact test. A micrograph of the fractured specimen is analysed using a scanning electron microscope (SEM).

\section{EXPERIMENTAL PART}

\subsection{Materials}

The most commonly used reinforcement in polymer composites is glass fibre due to its toughness, energy absorption and strength. In this work stainless steel mesh and woven glass fibre are used as the reinforcement. Epoxy (LY556) resin with hardener (HY951) was used as the matrix material. The SSWM enhances the cracking behaviour and energy-absorption capability, also the epoxy resin coating provides good corrosion resistance of the wire mesh. Also SSWM maintained constant weight percentage to achieve the same weight as in plain GFRP. The matrix material and woven glass fibre were purchased from Covai seenu brothers ltd, Coimbatore. The properties of the stainless-steel mesh and the woven glass fibre are illustrated in Table $\mathbf{1 .}$

Table 1: Properties of stainless-steel wire mesh and woven glass fibre Tabela 1: Lastnosti žične mreže iz nerjavnega jekla in tkanine iz steklenih vlaken

\begin{tabular}{|c|c|c|c|c|c|}
\hline $\begin{array}{c}\text { Reinforce- } \\
\text { ment } \\
\text { material }\end{array}$ & $\begin{array}{c}\text { Tensile } \\
\text { strength } \\
(\mathrm{MPa})\end{array}$ & $\begin{array}{c}\text { Yield } \\
\text { strength } \\
(\mathrm{MPa})\end{array}$ & $\begin{array}{c}\text { Density } \\
\mathrm{g} / \mathrm{cm}^{3}\end{array}$ & $\begin{array}{c}\text { Diameter } \\
\text { of wire } \\
(\mathrm{mm})\end{array}$ & $\begin{array}{c}\text { Width } \\
\text { between } \\
\text { wires } \\
(\mathrm{mm})\end{array}$ \\
\hline $\begin{array}{c}\text { Stainless } \\
\text { steel (SS304) }\end{array}$ & 620 & 275 & 8.0 & 0.5 & 1.6 \\
\hline $\begin{array}{c}\text { Woven glass } \\
\text { fibre }\end{array}$ & 500 & 170 & 2.54 & - & - \\
\hline
\end{tabular}

\subsection{Fabrication of composites}

The hand layup technique is used for preparing composite laminates. Before use, the woven AISI 304 SSWM is cleaned in an alkaline soap bath and is followed by a rinse in deionized water and allowed to dry in air. Then the flat mould surface is taken and cleaned thoroughly to avoid any foreign particles. A releasing agent (wax) was properly spread over a flat mould for easy removal of the composite. A thin layer of resin and hardener mixture in the ratio 10:1 is applied to the mould surface. Then woven glass fibre is placed over the thin layer of resin and filled with epoxy resin-hardener mixture. Then, by using the roller, the resin is rolled to remove the entrapped air and to ensure uniform spreading of the mixture. After each layer, a mixture of resin and hardener is rolled over and allowed to dry. In this way, several layers of woven glass fibre are placed, one over the other, and the same steps are repeated until the required thickness was obtained. Finally, the preprocessed SSWM is placed over the laminate evenly, and resin-hardener mixture with woven glass fibre is applied on the stainless-steel mesh and is allowed to cure. A weight of $8-10 \mathrm{~kg}$ is placed over the laminate and left undisturbed for a curing period of 4-5 h. Ensure the thickness of all the laminates that must be kept the same way as $3.2 \mathrm{~mm}$ for mechanical testing. The weight fraction of woven glass fibre is $50 \%$ of mass fractions, the epoxy resin is $40 \%$ of mass fractions, and the SSWM is $10 \%$ of mass fractions.

\section{COMPOSITES TESTING}

\subsection{Tensile test}

The specimens for conducting the tensile test in four categories such as Plain GFRP, Top mesh GFRP, Middle mesh GFRP and Bottom mesh GFRP are prepared according to ASTM D638 standards. The top and bottom mesh is the same geometry, but the test is conducted for both individually to obtain a clear load-bearing capability. The test is performed in a universal testing machine (UTM) at room temperature. The specimen is held between the grippers of the UTM, and the load is applied gradually and the corresponding deflections are recorded. The load is applied incessantly until the specimen breaks and the corresponding break load is noted.

\subsection{Flexural test}

The flexural test specimens are cut according to the ASTM D790 standard. The test is carried out in the UTM by placing the specimen on the two vertical supports. The load is applied transversely to the middle of the laminate until the specimen bends and fractures. Then the corresponding fracture load is noted and the graph is generated.

\subsection{Inter delamination}

The specimen is prepared according to ASTM D5528 standards. A delamination or interfaced crack is a crack that initiates and grows between the different plies of a composite. Delamination is a kind of failure in which the 
layers detach, resulting in a loss of strength. It is an internal mode of failure. The specimen is held between two vertical supports. The transverse load is applied until the fracture occurs. The corresponding fracture load is noted. The internal cracks are viewed through the macro images to identify their interfacial cracks.

\subsection{Drop weight impact test}

A vertical drop weight impact-testing machine is employed to perform the above test. For the drop-weight impact test the specimens are cut according to ASTM D7136 standard. The impactor guide mechanism releases an impactor of mass $2-5 \mathrm{~kg}$ at the desired height. A hemispherical tub is placed on the specimen that allows the material to attain the peak force and produces the shortest contact duration. The diameter of the tub is about $25.4 \mathrm{~mm}$. The laminate is impacted to produce damage and the resulting damaged area is captured through the macro images.

The above mechanical tests are performed in five replicates for each combination, and the average values are determined.

\section{RESULTS AND DISCUSSION}

\subsection{Tensile properties}

The tensile test is conducted on the fabricated composite specimen using the UTM. The values of the mechanical properties, such as break load, elongation and ultimate tensile strength, are shown in Table 2. The stress vs. strain graph is shown in Figure 1. Figure 1 shows that stress increases linearly with the strain for all the composites. Generally, the epoxy resin behaves like brittle materials when the fibre (SSWM, glass fibre) is

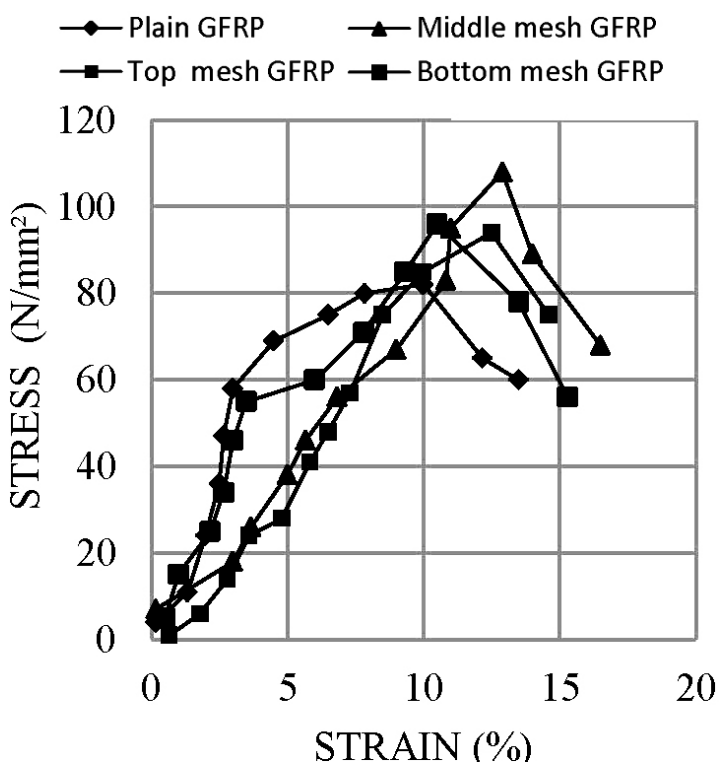

Figure 1: Stress vs. strain curve for tensile test Slika 1: Krivulja napetost-raztezek pri nateznem preizkusu loaded in the epoxy resin that behaves like ductile materials, which are shown in the stress-strain curve. ${ }^{15}$ For all the combinations, the stress and strain decrease after a particular point exhibiting ductile properties. For all the laminates, the stress and strain decrease after a particular point exhibiting ductile properties.

The first crack and ultimate load were generally improved with the increasing number of wire mesh layers. This is attributed to the fact that additional wire mesh provides more resistance to an increasing load and restraint of micro-cracks propagation. The overall results of the first cracks and failure load demonstrate the advantage of using wire mesh as an external method for enhancing the strength and the first crack. The first crack was delayed much better than the other enhancing techniques, such as internal steel fibres. ${ }^{16}$

Table 2: Tensile properties of GFRP-SSWM

Tabela 2: Natezne lastnosti GFRP-SSWM

\begin{tabular}{|c|c|c|c|}
\hline Laminate & $\begin{array}{c}\text { Ultimate break- } \\
\text { ing load }(\mathrm{N})\end{array}$ & $\begin{array}{c}\text { Ultimate tensile } \\
\text { strength }\left(\mathrm{N} / \mathrm{mm}^{2}\right)\end{array}$ & $\begin{array}{c}\text { Elongation } \\
(\%)\end{array}$ \\
\hline Plain & 1100 & 86 & 13.667 \\
\hline Top & 2900 & 95 & 14.900 \\
\hline Middle & 3600 & 110 & 16.833 \\
\hline Bottom & 3500 & 99 & 15.500 \\
\hline
\end{tabular}

The enhancement in the tensile strength is predominant in GFRP-SSWM laminate where the strength of GFRP improves from $86 \mathrm{MPa}$ to $110 \mathrm{MPa}$ when the SSWM is introduced in the middle of the laminate. In contrast, the elongation of GFRP-SSWM at the middle layer exhibits 1.23 times that of the plain GFRP, 1.09 times that of top layers and 1.13 times that of the bottom layer. Similarly, the ultimate strength of GFRP-SSWM at the middle layer is 1.28 times that of plain GFRP, 1.105 times that of the top layers and 1.151 times that of the bottom layer.

The tensile-test result shows that the performance of the GFRP-SSWM at the middle layer is higher than the other laminates. This signifies that the tensile properties of the GFRP improve with the inclusion of a stainlesssteel mesh in the middle of the laminate. The incorporation of SSWM layer into the epoxy matrix had a considerable effect on its tensile properties. The SSWM impregnated into the epoxy matrix, which improves the efficiency of the composites and prevents cracking in the cured product.

\subsection{Flexural properties}

The flexural properties together with the break load and the displacement of the composite are tabulated in Table 3. The flexural test is carried out in the state of stress experienced by the specimens can be extremely perplexing and several failure modes can occur, in particular fibre buckling and delamination. The harm zone so nucleated can cause longitudinal splitting, leading to premature failure of the composite laminate, 
thus preventing higher stresses in the outermost fibres to be reached. This event is less critical in glass-fibre laminates because glass fibres show lower modulus and higher elongation at the break. ${ }^{17}$ The loading phases of the specimens can be explained as follows. The first phase represents the elastic behaviour where there is no crack in the tension face and the specimen maintains its full flexural stiffness and rigidity. The load increases linearly with the deflection. The second phase corresponds to the initiation of cracks and reduction in the load and deflection. In this phase, the bending stiffness of the specimen reduced. The final phase includes the failure of wire mesh-epoxy composite and the fracture of the specimen. ${ }^{14}$

Table 3: Flexural properties of GFRP-SSWM

Tabela 3: Upogibne lastnosti GFRP-SSWM

\begin{tabular}{|c|c|c|}
\hline Laminate & $\begin{array}{c}\text { Breaking load } \\
(\mathrm{N})\end{array}$ & $\begin{array}{c}\text { Flexural strength } \\
\left(\mathrm{N} / \mathrm{mm}^{2}\right)\end{array}$ \\
\hline Plain & 310 & 75 \\
\hline Top & 480 & 80 \\
\hline Middle & 520 & 95 \\
\hline Bottom & 430 & 85 \\
\hline
\end{tabular}

It is understood from Table 3 that the result of the GFRP-SSWM at the middle layer is higher than that of all the other laminates. It was found that GFRP-SSWM at the middle layer has a higher ultimate breaking load than that of the other laminates. The ultimate strength of the GFRP-SSWM at the middle layer is higher than all the other laminates. The ultimate strength of GFRPSSWM at the middle layer is 1.266 times that of the plain GFRP (1.067 times that of the top layer and 1.133 times that of the bottom layer). From these discussions, it is observed that GFRP-SSWM at the middle layer has more flexural strength compared to all the laminates.

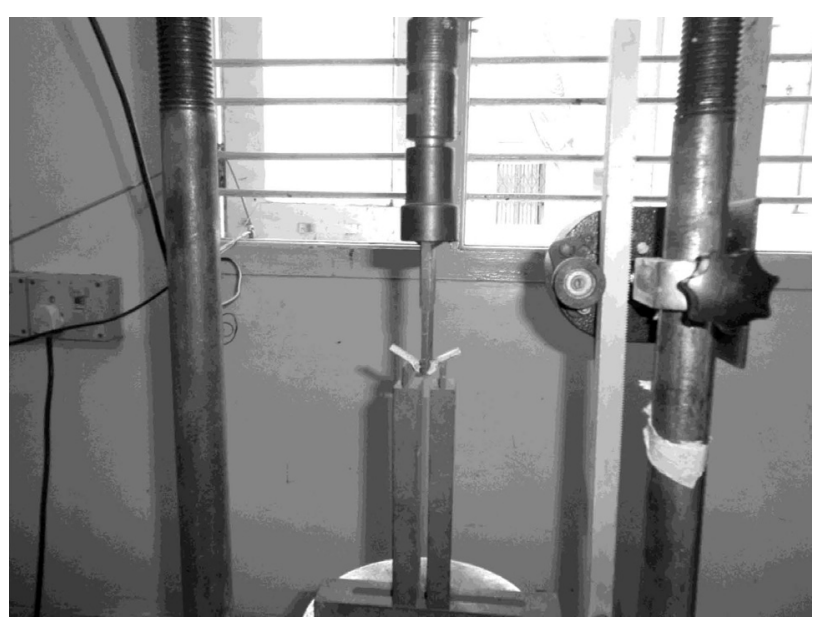

Figure 2: Inter-delamination test arrangement Slika 2: Naprava za preizkus razslojevanja

\subsection{Inter-delamination test}

Delamination is one of the modes of failure in composite laminate materials. Delamination is caused in a laminated composite due to fatigue stress. The various properties such as breaking load and the ultimate strength of the inter-delamination test are tabulated in Table 4. The inter-delamination test arrangement is shown in Figure 2.

Table 4: Inter delamination properties of GFRP-SSWM Tabela 4: Lastnosti razslojevanja GFRP-SSWM

\begin{tabular}{|c|c|c|}
\hline Laminate & $\begin{array}{c}\text { Ultimate breaking } \\
\text { load }(\mathrm{N})\end{array}$ & $\begin{array}{c}\text { Ultimate strength } \\
\left(\mathrm{N} / \mathrm{mm}^{2}\right)\end{array}$ \\
\hline Plain & 140 & 20 \\
\hline Top & 155 & 30 \\
\hline Middle & 180 & 36 \\
\hline Bottom & 170 & 32 \\
\hline
\end{tabular}

The maximum load is higher for the GFRP laminate with SSWM at the middle of the layer since it bears more load than all the other laminates. The load is increased from elastic region the SSWM resist more load as well as the load transfer being even throughout the composites because of the open metallic inserts.

It is clear from Table $\mathbf{4}$ that the ultimate breaking load of GFRP-SSWM at the middle layer is 1.286 times than that of plain GFRP (1.107 times than that of the top layer and 1.214 times than that of the bottom layer). Similarly, the ultimate strength of GFRP-SSWM at the middle layer is two times that of the plain GFRP (1.125 times that of the top layer and 1.5 times of bottom layer of the laminate). A macro image of the inter-delamination test specimens is shown in Figure 3.

From the results it is clear that the sequence of this SSWM increases the load-bearing capacity with a reduction of the weight and also improving the strength. With the proper sequence of materials and its varying properties the fracture and failure of laminates has been reduced. It is concluded that the GFRP at middle layer (SSWM) shows good results under the inter-delamination test compared to the other laminates.

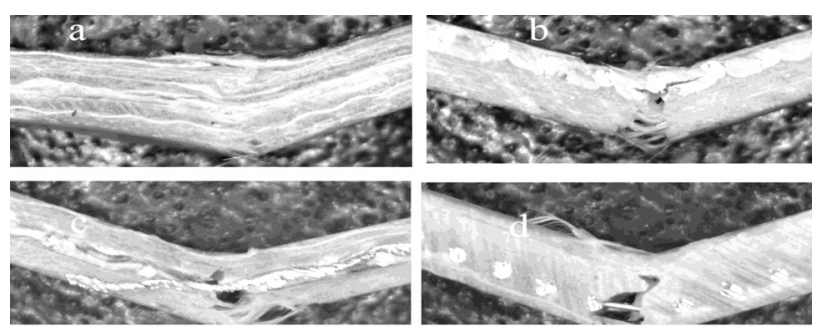

Figure 3: Macro image of inter delamination test specimens: a) plain GFRP laminate, b) top mesh GFRP laminate c) middle mesh GFRP laminate and d) bottom mesh GFRP laminate

Slika 3: Makroposnetek preizkusa notranjega razslojevanja: a) GFRP laminat, b) GFRP laminat z mrežo zgoraj, c) GFRP laminat z mrežo v sredini in d) GFRP laminat $\mathrm{z}$ mrežo spodaj 


\subsection{Drop-weight impact test}

The drop-weight impact test is used to determine the impact energy absorption capacity of the laminates. This impact characterization is essential for applications in the aeronautical and mechanical fields where crash aspects represent a key point. Figure 4 shows the result of the plain and hybrid laminate after the impact of a body of mass $2.5 \mathrm{~kg}$ at a height of $1 \mathrm{~m}$. The circle indicates that the damage is due to the drop-weight impact test.

Figure 4a illustrates the plain GFRP laminate that displays fibre and matrix crushing on the impact side with multilevel delamination through the thickness and finally tensile and buckling failure on the back surface.

Figure $\mathbf{4 b}$ reveals the GFRP-SSWM at the top layer of the laminate, where it displays modest evidence of crushing in the mesh region where the tough combination of the mesh reinforced epoxy absorbs much of the energy and the remaining energy is crushed in the fibre-matrix combination. The application of force to the laminate helps the stainless-steel mesh absorb the initial energy. The remaining energy will crush the fibre matrix combination. So the laminates are crushed less than the plain GFRP.

Similarly, Figure 4c shows that the GFRP-SSWM at the middle layer of the laminate, the impact energy is absorbed by a fibre matrix combination. So it absorbs a small amount of impact energy and then it faces the mesh reinforced epoxy and the remaining energy is absorbed in the middle layer itself. So the damage occurs in the GFRP-SSWM at the middle layer that is almost less when compared to all the other laminates.

Figure 4d shows that GFRP-SSWM at the bottom layer of the laminate displays the fibre matrix crushing till the bottom of the laminate and then it faces the mesh-reinforced epoxy. The $3 / 4^{\text {th }}$ of the laminate is crushed when the initial impact energy is applied to the
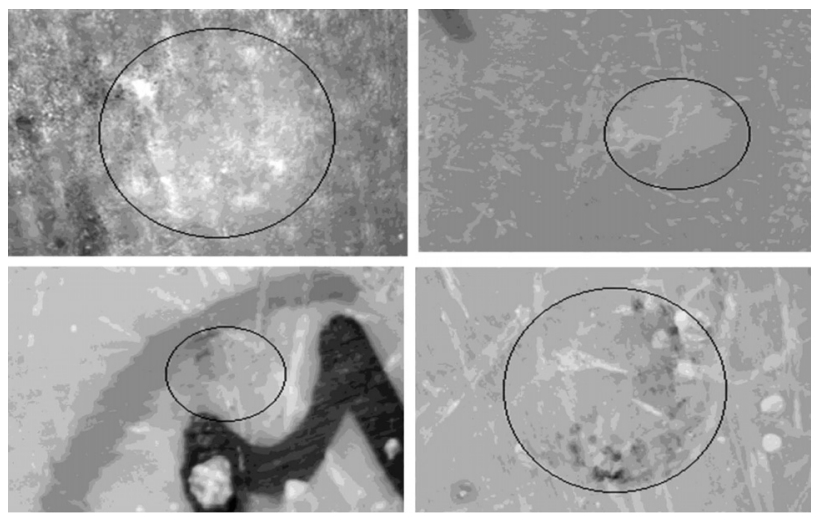

Figure 4: Macro image of drop-weight impact test specimens: a) plain GFRP laminate, b) top mesh GFRP laminate, c) middle mesh GFRP laminate and d) bottom mesh GFRP laminate

Slika 4: Makroposnetek vzorca pri udarnem preizkusu: a) GFRPlaminat, b) GFRP-laminat z mrežo zgoraj, c) GFRP-laminat z mrežo v sredini in d) GFRP-laminat z mrežo spodaj laminate. When the force is applied on the laminate almost all the impact energy is absorbed by the fibre matrix combination and the remaining amount of energy is impacted on the stainless-steel mesh. It is seen that these laminates are crushed more than the top layered mesh laminate but lesser than the plain GFRP.

\subsection{Morphological analysis}

The morphological analyses of the tested specimen were performed utilizing an SEM. The fractured specimens from the tensile and flexural tesst are examined utilizing SEM. The interfacial adhesion between the matrix and the fibre is clearly seen from the SEM images. The SSWM is visible in Figure 5 that are in the top, middle and bottom layers. An almost culminate infiltration into the wire meshes and merge between the woven glass fibre and the metal mesh reinforced epoxy could be achieved. There is no unsettling influence of the fibre structure close to the wires, as found in Figure 5a.

Figure $\mathbf{5 b}$ shows that there is no distinctive damage to the fibre or matrix. However, transversal fibre cracks

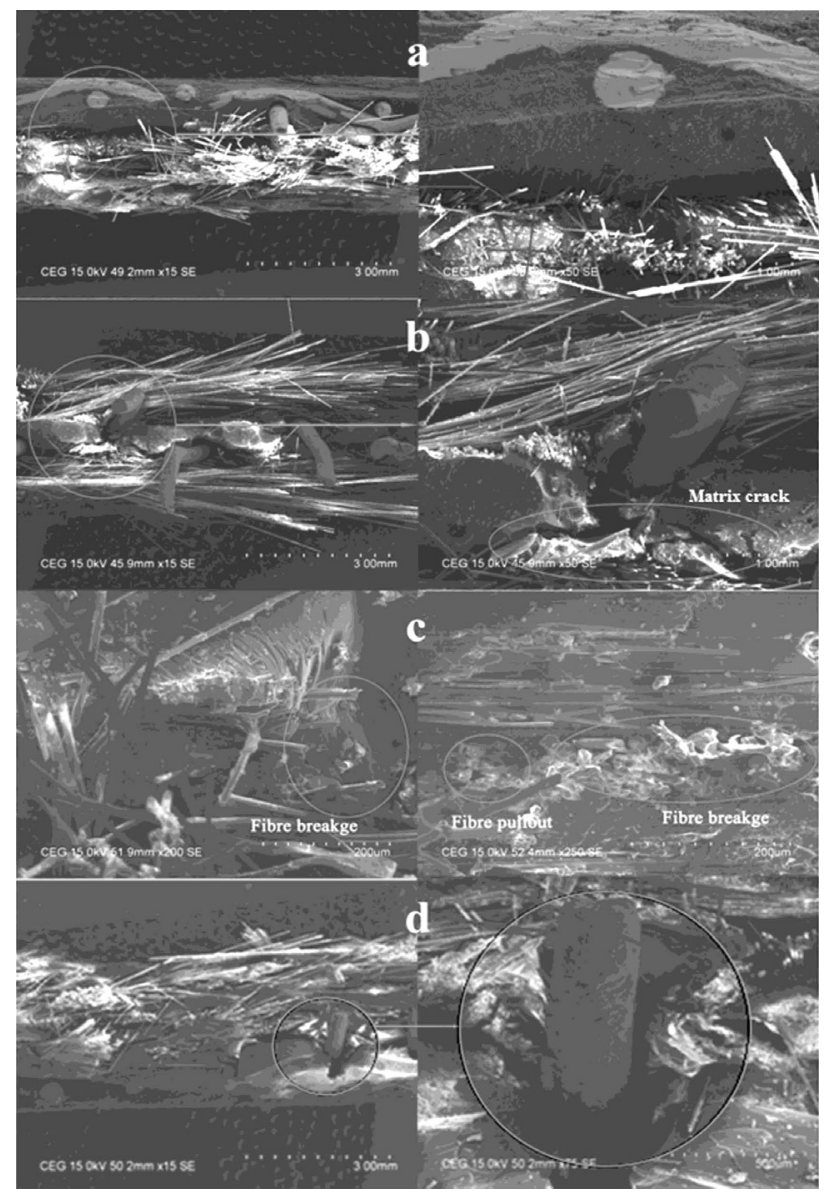

Figure 5: SEM images GFRP-SSWM laminate composites: a) top mesh GFRP laminate, b) middle mesh GFRP laminate, c) plain mesh GFRP laminate and d) bottom mesh GFRP composite

Slika 5: SEM-posnetek GFRP-SSWM laminatnega kompozita: a) GFRP-laminat z mrežo zgoraj, b) GFRP-laminat z mrežo v sredini, c) GFRP-laminat z običajno mrežo in d) GFRP-laminat mrežo spodaj 
can be detected where the disturbance of the fibre structure is high, and the fibres surround the wire very closely. This implies the fibres are seriously bent during a flexural load.

The SSWM in the middle layer is clearly visible in Figure 5b. A microcrack is formed, initiated and propagated through the matrix, and when it arrives at an interface, it continues along the interface up to the fracture of the fibre. After the fibre fractures, the crack propagates through the matrix and then moves to the next interface, this process continues until there is a complete fracture. The SSWM layer withstands the tensile load, which pulls the SSWM and matrix cracks.

Both fibre breakage and pullout are clearly visible in Figure 5c, where it is evident that the strength is lower compared to the other laminates. It is found that the fibres in the region of the loading region are more prone to damage. The strain values of the fibre in this region might have diminished and that leads to fibre pull-out.

A typical crater at the wire of the composite produced with a tensile force and also an interface debonding between the wire and the matrix is observed in Figure 5d. It also shows that the fibre/matrix interface of adjacent fabric layers. Figure 5d the circles illustrate the process-induced damage. The circle indicates a high tensile load as a result of a wire-induced distortion to the fibre structure at the maximum tensile force. Due to a purely elastic deformation at maximum force, a subsequent discharge leads to the elastic reshaping of the wire mesh. This leads to the debonding that occurs at the fibre/matrix interface.

\section{CONCLUSIONS}

The influence of a stainless-steel wire mesh layer on the mechanical behaviour of GFRP was investigated. From the above test results, the following conclusions are drawn:

- The ultimate strength and breaking load of GFRPSSWM at the middle layer is $110 \mathrm{MPa}$ and $3600 \mathrm{~N}$, respectively, which is higher than that of all the other laminates.

- From the tensile test, the percentage elongation of GFRP-SSWM in the middle layer is $16.83 \%$, which is higher than that of all the other laminates.

- In the flexural test, it is clear that GFRP-SSWM at the middle layer has an ultimate stress and breaking load of $95 \mathrm{MPa}$ and $520 \mathrm{~N}$, respectively, which is higher than that of the other composites.

- In the inter-delamination test, a breaking load of 180 $\mathrm{N}$ and ultimate strength of $36 \mathrm{MPa}$ were obtained for GFRP-SSWM at the middle layer, which is found to be greater than the other laminates.

- Similarly, in the drop-weight impact test, more impact energy is absorbed by the GFRP-SSWM at the middle layer that is higher and has less impression on the laminate compared to the other laminates.
- The treatment of the metallic surface may also contribute to an improvement of the wire/matrix interface. From this morphology study, it is evident that SSWM is a reinforcement material in the epoxy matrix.

- It was found that the GFRP- SSWM at the middle layer provides better results compared to the other laminates. Hence, the introduction of stainless-steel mesh in the middle layer improves the mechanical properties of GFRP.

\section{REFERENCES}

${ }^{1}$ B. D. Agarwal, L. J. Broutman, Analysis and performance of fibre composites, $2^{\text {nd }}$ ed., John Wiley\& Sons, 1990

${ }^{2}$ C. Soutis, Carbon fibre reinforced plastics in aircraft construction, Materials Science and Engineering, A, 412 (2005), 1-2, 171-176, doi:10.1016/j.msea.2005.08.064

${ }^{3}$ K. Friedrich, Z. Lu, A. M. Hager, Recent advances in polymer composites tribology, Wear, 190 (1996) 2, 139-144, doi:10.1016/00431648(96)80012-3

${ }^{4}$ P. B. Mody, T.W. Chou, K. Friedrich, Effect of testing conditions and microstructure on the sliding wear of graphite fibre/PEEK matrix composites, Journal of Materials Science, 23 (1988) 12, 4319-4330

${ }^{5}$ S. Carmisciano, I. M. De Rosa, F. Sarassini, A. Tamburrano, Basalt woven fibre reinforced vinyl ester composites: Flexural and electrical properties, Materials and Design, 32 (2011) 1, 337-342, doi:10.1016/ j.matdes.2010.06.042

${ }^{6} \mathrm{~T}$. Wittek, T. Tanimoto, Mechanical properties and fire retardance of bi-directional reinforced composite based on biodegradable starch resin and basalt fibres, Express Polymer Letter, 2 (2008) 11, 810-822, doi:10.3144/expresspolymlett.2008.94

${ }^{7}$ G. R. Villanueva, W. J. Cantwell, The high-velocity impact response of composite and FML-reinforced sandwich structures, Composite Science and Technology, 64 (2004) 1, 35-54, doi:10.1016/S02663538(03)00197-0

${ }^{8}$ A. Asundi, Y. N. Choi Alta, Fibre-metal laminates an advanced material for future aircraft, Journal of Materials Processing Technology, 63 (1997) 1-3, 384-394. doi:10.1016/S0924-0136(96)02652-0

${ }^{9}$ J. J. C. Remmers, R. D. Borst, Delamination Buckling of fibre-metal laminates, Composite Science and Technology, 6 (2001) 15, 2207-2213, doi:10.1016/S0266-3538(01)00114-2

${ }^{10}$ P. P. Camacho, C. M. L.Tavanas, R. De Oliveiro, A. T. Mangues, A. J. M. Fesseiro, Increasing the efficiency of composite single shear lap joints using bonded inserts, Composites Part B: Engineering, 36 (2005) 5, 372-383, doi:10.1016/j.compositesb.2005.01.007

${ }^{11}$ L. Fratini, V. F. Ruisi, Self-piercing riveting for aluminium alloyscomposite hybrid joints, The International Journal of Advanced Manufacturing Technology, 43 (2009), 61-66, doi:10.1007/s00170008-1690-3

${ }^{12}$ Z. Huang, S. Sugiyama, J. Yaragimoto, Hybrid joining the process for carbon fibre reinforced thermosetting plastic and thin metallic sheets by chemical bonding and plastic deformation, Journal of Materials Processing Technology, 213 (2013), 1864-1874, doi:10.1016/j.jmatprotec.2013.04.015

${ }^{13}$ H. Hasselbruch, A.Von Hehl, H. W. Zoch, Properties and failure behaviour of hybrid wire mesh/carbon fibre reinforced thermoplastic composites under quasi-static tensile load, Materials and Design, 66 (2015), 429-436, doi:10.1016/j.matdes.2014.07.032

${ }^{14}$ M. I. Ismail, Q. Payam Shafigh, Md. Zamin Jumaat, A. Ibrahim Abdull, Z. Ibrahim,U. Johnson Alengaram, The use of wire mesh-epoxy composite for enhancing the flexural performance of concrete beams, Materials and Design, 60 (2014) 11, 250-259, doi:10.1016/j.matdes.2014.03.075 


\section{MATERIALI IN TEHNOLOGIJE/MATERIALS AND TECHNOLOGY (1967-2017) - 50 LET/50 YEARS}

M. SAKTHIVEL, S.VIJAYAKUMAR: INFLUENCE OF STAINLESS-STEEL WIRE MESH ON THE MECHANICAL ...

${ }^{15}$ V. S. Sreenivasan, D. Ravindran,V. Manikandan, R. Narayanasamy, Mechanical properties of randomly oriented short Sansevieria cylindrica fibre/polyester composites, Materials and Design, 32 (2011) 4, 2444-2455, doi:10.1016/j.matdes.2010.11.042

${ }^{16}$ D. Soulioti, N. Barkoula, A. Paipetis, T. Matikas, Effects of fibre geometry and volume fraction on the flexural behaviour of steel-fibre reinforced concrete, Strain, 47 (2011) 1, 535-541, 10.1111/j.14751305.2009.00652.x

${ }^{17}$ M. I. Okereke, Flexural response of polypropylene/ E-glass fibre reinforced unidirectional composites, Composites Part B: Engineering, 89 (2016), 388-396. doi:10.1016/j.compositesb. 2016.01.007 